\title{
ANALISIS PEMBIASAAN PERILAKU HIDUP SEHAT PADA ANAK KELOMPOK B TK HARAPAN PERTIWI DESA ANGGALOMOARE KECAMATAN ANGGALOMOARE
}

\author{
Nurul Idhayani ${ }^{1)} *$, Dian Fatmawati ${ }^{1)}$ \\ ${ }^{1}$ Jurusan PG-PAUD, Universitas Muhammadiyah Kendari.Jln. KH.Ahmad Dahlan No.9, Kendari \\ 93127, Indonesia.
}

* Korespondensi Penulis. E-mail: nurulidhayani03@gmail.com, Telp: 085241553624

\begin{abstract}
Abstrak
Tujuan pelaksanaan penelitian ini adalah untuk mendeskripsikan pembiasaan perilaku hidup sehat pada anak kelompok B TK Harapan Pertiwi Desa Anggalomoare Kabupaten Konawe. Subjek dalam penelitian ini adalah anak kelompok B sebanyak 15 orang yang terdiri dari 8 anak perempuan dan 9 anak laki-laki serta 2 orang guru dan 7 orang tua anak. Jenis penelitian ini adalah penelitian kualitatif, yang diperoleh melalui hasil observasi, wawancara dan dokumentasi dan dianalisis berdasarkan 3 cara yakni, reduksi data, penyajian data dan penarikan kesimpulan. Hasil penelitian menunjukan bahwa pembiasaan perilaku hidup sehat pada anak kelompok B TK Harapan Pertiwi sudah dilaksanakan. Hal ini terlihat dari rutinitas cuci tangan yang dilakukan oleh murid-murid TK sebelum dan sesudah makan yang bisa dilakukan sendiri. Membuang sampah pada tempatnya. Membantu guru membereskan kelas atau peralatan belajarnya juga membersihkan ruangan sebelum dan sesudah makan juga setelah pelajaran usai, dan umumnya sudah bisa membereskan tempat bekal masing-masing setelah makan dan rata-rata tidak jajan sembarangan.
\end{abstract}

Kata Kunci :Pembiasaan, Perilaku Hidup Sehat

\section{AN ANALYSIS OF HEALTHY LIFE BEHAVIOR HABITUATION FOR CHILDREN IN GROUP B TK HARAPAN PERTIWI ANGGALOMOAREVILLAGE}

\begin{abstract}
The purpose of the implementation of this research was to describe the behavior of conditioning a healthy life on children's Group B TK Harapan Pertiwi Village Anggalomoare District Wowoni island. The subject in this study was 15 people consisting of 8 girls and 9 boys and 2 teachers and parents of children 7. This type of research is qualitative research, results obtained through observation, interview and documentation and analyzed based on three ways i.e., data presentation, data reduction and withdrawal of the conclusion. Results of the study showed that healthy living behavioral conditioning on Group B TK Harapan Pertiwi was implemented. This is apparent from the hand-washing routines performed by the pupils of TK Harapan Pertiwi before and after a meal can be done yourself. Dispose of trash in its place. Help teachers settle class or learning tools also sanitize before and after eating well after the lesson is over, and generally can already clinch the place of provision respectively after a meal and not average spending carelessly.
\end{abstract}

Keywords: Habituation, Behavior, Healthy Living

\section{PENDAHULUAN}

Kesehatan merupakan salah satu nikmat yang sangat berharga dalam kehidupan manusia.Kesehatan sebagai modal dasar untuk melakukan segala aktifitas.Menurut lembaga organisasi kesehatan dunia (WHO), kesehatan adalah keadaan yang sempurna baik fisik, mental, maupun sosial dan tidak hanya bebas dari penyakit dan cacat.Hal ini berarti kesehatan seseorang tidak hanya diukur dari aspek fisik, mental dan sosial saja, tetapi juga diukur dari 
produktifitasnya, di mana seluruh aspek kehidupan sangat mendukung kondisi kesehatan manusia.Banyak masalah-masalah kesehatan yang muncul di Indonesia maupun di dunia saat ini yang diakibatkan karena kurangnya kesadaran masyarakat untuk melakukan pola hidup bersih dan sehat. (Notoatmodjo, 2007:3).

Diantara kesehatan masyarakat yang terpenting adalah kesehatan bagi anak-anak. Masa anak-anak 0-6 tahun atau disebut golden age atau usia emas adalah usia yang sangat penting di mana perkembangan fisik, motorik, intelektual, emosional, bahasa dan sosial berlangsung dengan sangat cepat. Peningkatan pemeliharaan kesehatan bagi anak-anak sangat penting, karena kualitas anak sangat dipengaruhioleh kesehatan selama masa tumbuh kembang anak. Sehingga pendidikan kesehatan sangat strategis ditanamkan pada usia dini mengingat pada usia ini relatif belum terbentuk sikap dan perilakunya sehingga akan lebih mudah menanamkan perilaku hidup sehat dibanding orang dewasa. (Siswanto, 2009:29).

Menanamkan perilaku hidup bersih sedini mungkin lebih mungkin menjamin tercapainya masyarakat dengan perilaku hidup bersih dan sehat yang baik ketika mereka dewasa kelak. Kondisi yang lebih sehat sejak usia anak-anak akan memberi kesempatan tumbuhnya sumber daya manusia yang sehat dan berkualitas di masa depan. Selain itu masa anak-anak juga disebut sebagai masa kritis yang berarti bila pada masa ini anak mendapat gangguan atau kebutuhannya tidak tercukupi akan berdampak serius dan panjang baik terhadap kecerdasan, kesehatan, maupun sikap dan perilakunya.

Anis (2009:132) menyatakan bahwa anak-anak adalah amanah bagi orang tuanya.Hatinya masih putih, suci bagaikan permata. Maka jika mereka dikondisikan pada sesuatu yang baik serta diberi arahan dan diberi pendidikan, mereka akan tumbuh dan menjadi besar dengan sifat yang luhur dan bahagia dunia akhirat. Anak pada masa usia dini perlu mendapat pelayanan kesehatan yang lebih besar, karena daya tahan tubuhnya masih rendah sehingga mudah terinfeksi atau kekurangan gizi. Oleh karena itu, diperlukan perhatian khusus terhadap anak-anak tentang pendidikan dan pemantauan kesehatan dalam proses perkembangan mereka. Melalui pelaksanaan pendidikan Perilaku Hidup Sehat yang dilaksanakan oleh lembaga pendidikan kepada anak-anak usia dini, diharapkan kelak mereka mampu menerapkan hidup bersih dan sehat ketika dewasa.

Pendidikan anak pada dasarnya adalah tanggung jawab orang tua.Orang tua adalah pembina pribadi utama dalam kehidupan anak. Hanya karena keterbatasan kemampuan orang tua maka perlu adanya bantuan dari orang lainyang mampu dan mau membantu orang tua dalam pendidikan anak-anaknya terutama dalam pengajaran berbagai ilmu dan keterampilan yang selalu akan berkembang dan dituntut pengembangannya bagi manusia. Melalui pelaksanaan pendidikan Perilaku Hidup Sehat yang dilaksanakan oleh lembaga pendidikan kepada anak-anak usia dini, diharapkan kelak mereka mampu menerapkan hidup bersih dan sehat setelah dewasa (Daradjat, 1996:53).

Proses pembelajaran di TK juga senantiasa memperhatikan kesehatan anak, karena anak yang sehat akan dapat memperlancar proses kegiatan belajar mengajar. Anak yang sehat adalah dapat tumbuh dan berkembang dengan baik, jiwanya berkembang sesuai umur, bersih, gembira, pola hidup teratur dan bisa menyesuaikan dengan lingkungan sekitar. Aspek kesehatan sangat penting dalam kehidupan anak, termasuk dalam proses pendidikan, maka perlu adanya pembiasaan yang diterapkan pada anak tentang hidup sehat sejak awal, sehingga akan membentuk pola hidup sehat dikemudian hari. Dalam hal ini perlu adanya pendidikan kesehatan, yaitu proses perubahan perilaku secara terencana pada diri individu, kelompok, atau masyarakat untuk dapat lebih mandiri dalam mencapai tujuan hidup sehat. (Suliha, 2001:3).

Anak-anak usia TK sangat penting diajarkan pengembangan perilaku, terutama perilaku hidup yang sehat. Sesuai dengan lingkup perkembangan anak usia dini, yaitu meliputi nilai agama dan moral, fisik motorik, kognitif, bahasa, sosial emosional. Pembiasaan hidup sehat merupakan salah satu indikator pencapaian perkembangan sosial emosional. Dengan tidak meninggalkan prinsip pembelajaran di Taman Kanak-kanak yaitu belajar sambil bermain, karena dengan bermain merupakan kegiatan yang praktis dan dapat digunakan sebagai media untuk meningkatkan keterampilan dan kemampuan tertentu pada anak.

Berdasarkan hasil observasi awal yang dilakukan pada pertengahan bulan Desember tepatnya pada tanggal 12-24 Desember 2016 di TK Harapan Pertiwi Desa Anggalomoare 
Kecamatan Anggalomoare penulis menemukan bahwa TK ini belum melaksanakan pendidikan kesehatan dengan baik dalam hal ini perilaku hidup sehat. Sehingga terlihat keadaan yang kurang baik pada diri anak. Terlihat dengan masih banyak anak yang tingkat perilaku hidup sehatnya kurang, yaitu dari 15 orang anak hanya 3 orang anak yang melakukan perilaku hidup sehat di kelompok B. Sedangkan, 12 orang anak lainnya tidak melakukan perilaku hidup sehat seperti masih ada anak yang membuang sampah sembarangan, berpakaian kurang rapi, tidak memotong kuku. Jadi, sangat terlihat bahwa pembiasaan perilaku hidup sehat pada anak kelompok B TK harapan Pertiwi masih kurang diterapkan.

Oleh karena itu, penulis tertarik untuk menganalisis mengapa pada kelompok B tersebut yang berjumlah 15 orang anak masih banyak terlihat tingkat perilaku hidup sehatnya dinilai kurang. Maka penulis akan mengangkat permasalahan yang terjadi di TK Harapan Pertiwi Desa Anggalomoare Kecamatan Anggalomoare tersebut menjadi sebuah penelitian malalui Penelitian Kualitatif dengan judul "Analisis Pembiasaan Perilaku Hidup Sehat Pada Anak Kelompok B Di TK Harapan Pertiwi Desa Anggalomoare Kecamatan Anggalomoare Kabupaten Konawe".

\section{METODE}

Jenis penelitian yang digunakan dalam penelitian ini adalah deskriptif kualitatif, yang bertujuan untuk memberikan gambaran mengenai pembiasaan perilaku hidup sehat pada anak kelompok B di TK Harapan Pertiwi Desa Anggalomoare yang dilaksanakan pada Bulan Maret sampai Mei 2017, bertempat di TK Harapan Pertiwi Desa Anggalomoare Kecamatan Anggalomoare. Subyek dalam penelitian ini berjumlah 15 orang anak, 7 orang laki-laki dan 8 orang anak perempuan yang berada di kelompok B serta 2 orang guru dan 7 orang tua anak di TK Harapan Pertiwi Desa Anggalomoare.

Untuk memperoleh data-data yang diperlukan dalam penelitian ini digunakan teknik pengumpulan data dengan cara : (1) observasi, adalah pengamatan dan pencatatan yang dilakukan terhadap obyek ditempat terjadi atau berlangsungnya peristiwa sehingga observer berada bersama obyek yang diselidiki (Rachman, 1999:77). Melalui pengamatan, peneliti dapat berpartisipasi dalam rutinitas subyek peneliti baik mengamati maupun mendengarkan apa yang subyek lakukan. Oleh karena itu, dalam observasi menggunakan buku catatan dan cheklist.Hal-hal yang diamati atau diobservasi adalah perilaku hidup sehat anak di TK Harapan Pertiwi Desa Anggalomoare; (2) wawancara, mengadakan pertanyaan langsung kepada informan dengan menggunakan pedoman wawancara yang dapat memberikan informasi dalam menjawab permasalahan penelitian ini. Adapun materi wawancara berkaitan dengan bagaimana Pembiasaan Perilaku Hidup Sehat Pada Anak Kelompok B TK Harapan Pertiwi Desa Anggalomoare Kecamatan Anggalomoare; (3) dokumentasi, metode ini digunakan untuk memperoleh data tertulis dari sumber-sumber yang ada, yaitu dari dokumentasi di TK Harapan Pertiwi Desa Anggalomoare Kecamatan Anggalomoare.

Data yang diperoleh dari hasil penelitian, dianalisis dengan cara yang dilakukan oleh Miles dan Huberman (1992), yakni: (1) reduksi data; (2) penyajian data; dan (3) penarikan kesimpulan. Mengenai ketiga hal tersebut diatas dapat diuraikan sebagai berikut. Pertama, reduksi data yang dimaksud yaitu, data yang diperoleh ditulis dalam bentuk laporan atau data yang terperinci.Laporan yang disusun berdasarkan data yang diperoleh direduksi, dirangkum dipilih hal-hal yang pokok, difokuskan pada hal-hal yang penting. Kedua, penyajian data yang dimaksud yaitu, sesudah mereduksi data maka langkah selanjutnya adalah, menyajikan data dalam bentuk teks naratif. Ketiga, penarikan kesimpulan yang dimaksud yaitu, tahap ketiga dimana kesimpulan awal masih bersifat sementara dan akan berkembang ketika peneliti berada di lapangan.

\section{HASIL DAN PEMBAHASAN}

Sebagaimana yang telah dikemukakan sebelumnya bahwa kegiatan penelitian ini diupayakan dan diarahkan pada pencapaian tujuan untuk menganalisis pembiasaan perilaku hidup sehat pada anak.

Untuk maksud tujuan yang dipaparkan tersebut maka dalam penelitian ini diupayakan seoptimal mungkin memperoleh data-data mengenai hasil penelitian dan pengamatan terhadap beberapa aspek yang relevan dengan tujuan penelitian tersebut penulis akan memaparkan sebagai berikut:

\section{Catatan Lapangan}

Hari, Tanggal : Senin, 10 April 2017

Tempat : Sekolah TK Harapan Pertiwi 
Waktu

$$
\text { :07.00 Pagi }
$$

\section{Catatan Deskriptif}

Umumnya anak-anak murid TK Harapan Pertiwi Desa Anggalomoare berpenampilan rapi dengan seragam yang bersih, kulit bersih, menggunakan alas kaki, dan baju disetrika rapi. Pada jam 08.00 anak sudah memasuki ruangan kelas masing-masing. Peneliti bersama guru kelas B memasuki rungan kelas kelompok B.

Pada saat pembelajaran berlangsung guru mengingatkan anak agar sampah-sampah yang ada disekitar tempat duduk mereka harus dibuang dan peneliti melihat anak-anak tersebut mengikuti arahan guru mereka, sehabis mereka menggunting merekapun langsung membuang kertas-kertas tersebut ditempat sampah bahkan ketika masih ada sisa-sisa kertas yang berhamburan dibawah kursi dan meja, mereka langsung memungut dan membuangnya ketempat sampah yang ada didalam kelas.

\section{Catatan Reflektif}

Melihat hal demikian, Ini menunjukan bahwa hidup sehat sudah menjadi kebiasaan sehari-hari. Anak terlihat rapih dan bersih ketika datang sekolah dan anak telah menunjukan sikap taat dan patuh akan perintah dan arahan guru dengan membuang sampah, walaupun tidak disadari secara langsung bahwa mereka telah melakukan perilaku hidup sehat yaitu dengan membuang sampah pada tempatnya, hal ini menunjukan bahwa guru telah mengajarkan untuk membuang sampah pada tempatnya.

Hari, Tanggal : Rabu, 12 April 2017

Tempat: Sekolah TK Harapan Pertiwi

Waktu : 08.00 Pagi

\section{Catatan Deskriptif}

Peneliti melihat selama proses kegiatan pembelajaran berlangsung anak-anak tampak serius mengikuti pembelajaran dan melakukan setiap tugas-tugas kegiatan yang telah diberikan oleh gurunya. Setiap bel tanda istirahat berbunyi guru senantiasa mengajak anak-anak untuk mencuci tangan sebelum makan.Pelaksanaan pembiasaan cuci tangan diawali dengan guru menerangkan pentingnya menjaga kebersihan dengan melalui gerakan cuci tangan dengan menggunakan sabun sebelum dan sesudah makan.Peneliti melihat guru mendemonstrasikan cara cuci tangan yang baik dan benar dan anakanak diminta untuk menirukannya dan melakukannya setiap hari. Ketika peneliti mengikuti anak menuju kamar mandi untuk mencuci tangan, peneliti melihatkegiatan cuci tangan ini tidak disertai dengan pengawasan dalam pelaksanaanya oleh guru sehingga kegiatan cuci tangan tidak terkontrol dengan baik. Peneliti menemukan dalam satu kelas setidaknya ada 3 orang anak yang tidak mencuci tangan sebelum makan, 7 orang anak melakukan cuci tangan hanya sekedar membasahi tangannnya dengan air tanpa memakai sabun. Selain itu peneliti juga melihatguru lupa untuk menyediakan sabun cuci tangan dan serbet bersih yang kering.

\section{Catatan Reflektif}

Melihat keadaan tersebut, ini menunjukan belum adanya koordinasi yang tegas pada kegiatan mencuci tangan. Sehingga perlu adanya kontrol dari guru atau pembagian tugas untuk mengawasi anak cuci tangan agar pelaksanaan cuci tangan dapat berjalan dengan baik dan sesuai dengan standar kesehatan selain itu juga guru harus memperhatikan sebelum kegiatan cuci tangan dilakukan oleh anak sebaiknya sabun dan lap kering sudah harus lebih dulu disiapkan .

Hari, Tanggal : Senin, 17 April 2017

Tempat : Sekolah TK Harapan Pertiwi

Waktu :07.00 Pagi

\section{Catatan Deskriptif}

Diawal pembukaan pelajaran, guru bercakap-cakap pada anak-anak tentang kegiatan mereka dihari libur yakni pada hari minggu, ada anak yang menceritakan tentang kegiatan di rumah, ada yang menceritakan pengalaman-pengalaman yang mereka dapatkan diluar rumah dan lain sebagainya. Ketika percakapan tersebut berlangsung guru menanyakan kembali pada anak siapa yang mengingat dan mengerjakan pesan yang disampaikan guru pada hari sabtu yaitu untuk membersihkan pakaian sendiri dan memotong kuku, anak-anakpun langsung mengangkat tangan mereka dan guru mengatakan akan memeriksa kembali apakah betul dilakukan atau tidak. Pada saat guru melakukan pemeriksaan kuku peneliti ikut memperhatikan dan mengamati langsung kegiatan tersebut dan peneliti melihat kebersihan kuku anak sudah mulai terjaga karena rata-rata kuku anak tampak bersih dan tidak panjang. Penulis mendapati ada 3 orang anak saja yang masih terlihat tampak 
kurang membersihkan kotoran-kotoran yang berada disela-sela kuku mereka. Ketika ada anak yang terlihat kukunya masih kurang bersih guru dengan segera mengarahkan dan membantu anak untuk segera membersihkannya.

\section{Catatan Reflektif}

Kebersihan kuku anak haruslah selalu terjaga agar tidak terjadi hal demikian seperti masih ada anak yang memiliki kuku kotor disela-sela tangan. Dengan memperhatikan kebersihan kuku anak berarti kita telah melakukan pencegahan agar anak terhindar dari kuman-kuman penyakit.

Hari, Tanggal : Selasa, 18 April 2017

Tempat: Sekolah TK Harapan Pertiwi

Waktu : 08.00 Pagi

\section{Catatan Deskriptif}

Guru bercakap-cakap sambil mengajukan pertanyaan kepada anak siapa yang sarapan pagi kesekolah dan anak-anak mengacungkan tangannya menandakan bahwa ia sarapan pagi dan ada juga yang langsung mengatakan tidak, ditengah percakapan guru juga tak lupa untuk mengingatkan anak agar setiap selesai makan mereka harus langsung menggosok gigi dan juga langsung bertanya kembali pada anak apakah ada yang tidak gosok gigi datang kesekolah. Peneliti melihat guru tampak akan melakukan pemeriksaan gigi pada anak setelah menanyakan pertanyaan tersebut dan penelitipun dengan segera mengamati proses pemeriksaan gigi yang akan dilakukan guru kelompok B. Pada saat peneliti melihat guru memeriksakan gigi anak satu persatu, ditemukan gigi anak-anak tersebut terlihat putih dan bersih serta peneliti juga melihat guru mempraktekkan cara menggosok gigi yang baik dan benar.

\section{Catatan Reflektif}

Pemeriksaan gigi yang dilakukan oleh guru sudah baik, hal ini menunjukan bahwa anak-anak tersebut sudah mampu memperhatikan kesehatan gigi mereka. Pembiasaan menggosok gigi ini memang harus betul-betul ditanamkan agar anak-anak menjadi terbiasa menggosok gigi mengingat gigi anakanak rawan keropos dan berlubang.

Hari, Tanggal : Rabu, 19 April 2017

Tempat : Sekolah TK Harapan Pertiwi

Waktu :08.30 Pagi

\section{Catatan Deskriptif}

Proses pembelajaranpun berlangsung dengan tenang tanpa mempengaruhi keadaan anak yang berada dalam ruangan yang berjumlah sedikit. Pembelajaran berlangsung hingga bel tanda istirahat berbunyi. Anakanakpun langsung merapikan alat tulis dan memasukan kedalam tas sambil menunggu arahan guru untuk mempersilahkan mengeluarkan bekal mereka, sebagaimana kebiasaan yang sering dilakukan mereka yaitu makan siang bersama ketika waktu istirahat.

\section{Catatan Reflektif}

Pembiasaan makan bersama ini sudah baik untuk dilakukan agar-agar anak lebih terbiasa untuk makan makanan yang sehat dan disediakan oleh orang tua masing-masing, sehingga kebersihan dan kandungan makanan yang mereka konsumsi lebih terjamin kesehatannya daripada anak-anak harus jajan sembarangan yang tidak terjamin kesehatannya.

Hari, Tanggal : Jum`at, 21 April 2017

Tempat : Sekolah TK Harapan Pertiwi

Waktu :08.00 Pagi

\section{Catatan Deskriptif}

Hari ini tidak seperti hari-hari biasanya dimana jam sekolah anak terbatas hanya sampai pada jam sembilan saja dikarenakan hari ini adalah hari jumat. Mengingat jam pelajaran yang dilakukan hari ini terbatas tugas yang diberikan pada anakpun sedikit, hanya ada satu tugas saja dan ketika saat proses belajar mengajar berlangsung terdapat salah seorang anak di kelompok B meminta izin kepada guru untuk ke kamar mandi untuk buang air kecil. Peneliti membantu anak tersebut dengan mengantar kekamar mandi dan peneliti melihat bahwa anak tersebut sudah mampu menggunakan jamban dengan baik tanpa harus dibantu oleh guru dan orang tua. Selain anak tersebut peneliti juga melihat anak-anak kelompok B rata-rata telah mampu menggunakan jamban dengan baik, terutama ketika mereka akan BAK dan BAB tanpa meminta bantuan, peneliti juga melihat kamar mandi/WC yang tersedia hanya 1 ruangan.

\section{Catatan Reflektif}

Penggunaan jamban oleh anak-anak tampaknya sudah mampu dilakukan dengan sendiri, ini menunjukan bahwa adanya perilaku sehat yang sudah mereka tunjukkan dengan 
menggunakan jamban tanpa meminta bantuan. Akan tetapi hal yang ditakutkan apabila ada anak yang ingin menggunakan jamban secara bersamaan sehingga perlu antisipasi yang dilakukan oleh pihak sekolah.

Hari, Tanggal : Selasa, 25 April 2017

Tempat : Sekolah TK Harapan Pertiwi

Waktu : 07.00 Pagi

\section{Catatan Deskriptif}

Hari ini di TK Harapan Pertiwi rutinitas yang dilakukan masih tetap sama dengan masuk kelas pada jam yang telah ditentukan. Pada saat tugas kegiatan anak telah selesai dikerjakan dan beberapa anak ada yang sibuk bermain didalam kelas, peneliti meminta izin kepada kepala sekolah untuk keluar kelas. Peneliti berjalan mengelilingi lingkungan sekolah, sambil melihat-lihat keadaan sekolah. Ketika peneliti sedang melihat-lihat, peneliti menemukan kondisi halaman sekolah TK Harapan Pertiwi tampak bersih tidak ada daun-daun bertebaran, dan halaman tertata rapi walaupun ada beberapa saja tanaman hias yang rimbun sehingga perlu pemangkasan .

\section{Catatan Reflektif}

Kebersihan lingkungan di TK ini sudah mulai terjaga dan perlu ditingkatkan lagi, seperti pemankasan tumbuhan yang rimbun harus selalu diperhatikan agar TK ini tetap bersih dan indah karena hidup sehat bukan hanya sekedar kebersihan diri tetapi juga kebersihan lingkungan.

\section{Catatan Wawancara}

\section{a. Guru}

Peneliti mengajukan beberapa butir pertanyaan kepada guru kelas B yang diantaranya adalah: Apakah menurut ibu pembiasaan hidup sehat itu penting untuk ditanamkan sejak usia dini? Ibu Fitriani menjawab:

"Iya perlu sekali ditanamkan sejak usia dini, karena hidup sehat itu merupakan hal yang sangat penting untuk anak usia dini dimana mereka bisa mengerti tentang arti hidup sehat baik kesehatan diri mereka sendiri maupun lingkungan".

Apakah ada pembiasaan perilaku hidup sehat yang diajarkan pada anak usia dini di TK ini? Ibu Fitriani menjawab; "Iya ada". Pembiasaan hidup sehat apa saja yang ibu ajarkan kepada anak usia dini? Ibu Fitriani menjawab:
"Mandi, gosok gigi, kuku tangan dan kaki harus dipotong supaya bersih, cuci tangan, buang sampah di tempatnya, dan lain-lain".

Bagaimana ibu mengajarkan hidup sehat untuk anak usia dini? Ibu Fitriani menjawab:

"Mencuci tangan, bila anak yang baru saja masuk sekolah anak diajarkan mencuci tangan dengan mempraktekkan langsung pada anak cara mencuci tangan yang baik dan benar dengan sabun serta air kemudian dikeringkan dengan lap bersih kegiatan ini dilakukan secara teratur sebelum dan sesudah makan dan dibuat sebagai kegiatan pembiasaan setiap harinya. Kebersihan kuku, setiap hari sabtu saya menganjurkan pada anak untuk memotong kuku yang sudah panjang dan pada hari senin dilakukan pemeriksaan kuku. Gosok gigi, pertama-tama anak diajarkan cara menggosok gigi yang baik dan benar dan mengingatkan anak agar menggosok gigi 3 kali sehari. Membuang sampah, anak diajarkan untuk membuang sampah pada tempatnya dan tiap-tiap kelas disediakan dua tempat sampah didalam dan didepan kelas selain itu ada kegiatan bersihbersih ruangan, menata mainan, dan menjaga kebersihan kelas. Kebersihan pakaian, anak dianjurkan untuk mencuci pakaian sendiri dihari minggu dan pada hari senin saya memeriksa kebersihan dan kerapihan pakaian mereka. BAB dan BAK dikamar mandi, anak-anak dibiasakan untuk buang air besar dan kecil di WC pada awalnya saya membantu membersihkan diri mereka sambil mengajarkan anak selanjutnya anak dibiasakan membersihkan dirinya sendiri dan diajarkan untuk menggunakan tangan kiri serta memakai sabun dan saya tetap mendampingi anak. Kebersihan lingkungan, kadang-kadang anak-anak juga saya ajak melakukan gotong royong secara berkelompok untuk membersihkan lingkungan."

Apa kendala dari pembiasaan hidup sehat pada anak usia dini? Ibu Fitriani menjawab:

"Biasanya anak selalu lupa, harus selalu sabar dalam menjelaskan secara detail tentang tata cara hidup sehat dan mengingatkan secara terus menerus".

Adakah dukungan dari pemerintah atau warga untuk membantu terlaksananya hidup sehat di sekolah? Ibu Fitriani menjawab: 
"Sedikit, yaitu kadang sering didatangkan makanan tambahan dari puskesmas kecamatan tetapi pelatihan tentang perilaku hidup sehat tidak ada, terutama saya pribadi belum sama sekali mengikuti pelatihan tersebut".

Apa kekurangan dan kelebihan dari pembiasaan perilaku hidup sehat di TK Harapan Pertiwi ini? Ibu Fitriani menjawab:

"Kekurangannya yaitu kurangnya media pembelajaran yang mendukung pembelajaran kesehatan bagi anak, kelebihannya yaitu fasilitas cukup tersedia dan tinggal melanjutkan saja".

Apa harapan ibu untuk meningkatkan hidup sehat anak usia dini? Ibu Fitriani menjawab:

"Harapan saya adalah kita harus selalu bekerja sama baik antara orang tua maupun pihak pemerintah dalam meningkatkan hidup sehat bagi anak-anak kita di usia dini ini".

Peneliti melihat guru sangat antusias dan baik dalam menjawab setiap butir pertanyaan yang peneliti ajukan tanpa adanya ragu-ragu atau jawaban yang dibuat-buat oleh guru tersebut.

\section{b. Orang tua anak}

Wawancara pertama yang dilakukan peneliti yakni pada Ibu Hastina orang tua dari Rizqiah Azzahra, dengan beberapa pertanyaan diantaranya adalah:

Apakah menurut anda pembiasaan hidup sehat itu penting untuk diajarkan di rumah? Apa alasan anda? Ibu Hastina menjawab:

"Iya penting, yah supaya anak saya sehat".

Pembiasaan hidup sehat apa saja yang sudah anda ajarkan di rumah ? Ibu Hastina menjawab:

"Di rumah saya ajarkan cuci tangan terutama sebelum makan dan sesudah makan, gosok gigi, potong kuku, mandi, makan sayuran, buang sampah, bersihkan tempat tidurnya, dan juga saya ajarkan untuk membersihkan kotorannya jika BAB".

Bagaimana perilaku hidup sehat anak anda di rumah? Ibu Hastina menjawab:

"Anak saya kalau di rumah mandi sendiri kadang juga dimandikan, anak saya biasanya mandi dalam sehari dua kali kadang tiga kali menggunakan sabun mandi, sikat gigi setiap dua kali sehari pada saat pagi dan sore bersamaan saat mandi, menggunakan shampo pagi dan sore hari, cuci tangan sebelum makan, dan anak saya juga sudah bisa membersihkan kotorannya sendiri ketika BAK dan BAB dengan menggunakan sabun".

Apa saja yang anda upayakan untuk menjaga kesehatan anak anda? Ibu Hastina menjawab:

"Saya upayakan agar pembiasaan yang saya terapkan ini tidak berhenti atau putus-putus supaya anak saya selalu terbiasa hidup sehat hingga mereka besar nanti, oleh karena itu saya mengajarkan secara terus menerus kepada anak saya untuk cuci tangan sebelum makan, mandi, gosok gigi, makan sayuran, dan lain-lain".

Apa kendala dari pembiasaan hidup sehat pada anak anda? Ibu Hastina menjawab:

"Kendalanya adalah kalau anak saya kadang malas untuk melakukannya dikarenakan asik main game atau ada kegiatan lain yang dilakukannya sehingga saya juga harus selalu memaksanya sampai ia melakukan misalnya makan dan gosok gigi".

Apa pendapat anda terhadap pembiasaan perilaku hidup sehat di TK Harapan Pertiwi? Ibu Hastina menjawab:

"Sudah bagus dan semoga ditingkatkan lagi fasilitasnya juga sarana dan prasarananya seperti kamar mandi di TK ini hanya ada 1 ruangan, selain itu juga harus diperhatikan kebersihan lingkungan sekolahnya".

Apa kritik atau saran anda untuk kemajuan perilaku hidup sehat di TK Harapan Pertiwi? Ibu Hastina menjawab:

"Pihak sekolah seharusnya lebih memperhatikan lagi keadaan sekolah ini terutama sarana prasarananya yang belum terlalu lengkap seperti kamar mandi tadi hanya ada 1 ruangan oleh karena itu pesan saya agar di perhatikan sarana prasarananya maupun juga kebersihan lingkungannya sekolahnya.".

Peneliti melakukan wawancara kepada orang tua anak sebanyak 7 orang dengan pertanyaan sama seperti diatas dan peneliti menemukan rata-rata memberikan jawaban yang sama mengenai perilaku hidup sehat anak di rumah hanya kendala yang mereka dapatkan sedikit berbeda-beda, misalnya ada orang tua yang mendapatkan kendala anak mereka lupa sehingga harus selalu diingatkan, ada yang anaknya manja sehingga harus dibujuk dan dirayu, dan ada juga anak yang biasa menundanunda untuk melakukan perilaku hidup sehat 
tersebut. Selain kendala yang berbeda-beda tersebut ada juga beberapa orang tua yang mengatakan sangat terbantu dengan adanya pembiasaan hidup sehat yang dilakukan disekolah karena anak mereka sudah bisa mandiri.

\section{Perilaku Hidup Sehat Anak di TK Harapan Pertiwi Desa Anggalomoare}

Berdasarkan hasil observasi, umumnya murid-murid di TK Harapan Pertiwi sudah mulai bisa berperilaku hidup sehat walaupun masih perlu bimbingan dalam pelaksanaannya.Karena dari hasil observasi penulis, ada beberapa anak yang belum melakukan gerakan cuci tangan secara baik dan benar.Misalnya gerakan cuci tangan hanya sekedar membasahi tangannya dengan air tanpa mengusap kedua tangan dengan menggunakan sabun.Hal ini tentu saja tidak sesuai dengan standar mencuci tangan yang baik, mencuci tangan seharusnya dilakukan dengan menggosok seluruh tangan dan sela-sela tangan sampai bersih menggunakan sabun dan bilas dengan air yang mengalir.Kegiatan cucitangan yang dilakukan anak hanya sekedar untuk memenuhi anjuran guru.

Kegiatan mencuci tangan hanya memenuhi ranah kognitif dan afektifnya saja, belum sampai ke ranah psikomotor. Pada saat peneliti melakukan wawancara langsung dengan orang tua dari salah satu anak yang tidak cuci tangan yaitu ibu Atriani (17 April 2017), beliau mengatakan: "anak saya memang tidak saya perbolehkan mencuci tangan sendiri, karena anak saya suka main air kalo disuruh cuci tangan kecuali saya sendiri yang mencuci tangannya."

Hal ini menunjukkan sebenarnya perilaku anak yang tidak mencuci tangan di lingkungan sekolah sangat dipengaruhi oleh pendidikan yang didapat saat berada di rumah. Bila guru di sekolah juga tidak memperlakukan dengan ketat kegiatan cuci tangan di sekolah, hal ini menunjukkan tidak akan terjadi perubahan perilaku hidup sehat pada anak. Ini berarti pendidikan di sekolah tanpa adanya pengawasan dari guru tidak akan menghasilkan perubahan perilaku apapun pada anak.

Anak sudah bisa membuang sampah pada tempatnya namun terkadang masih perlu bimbingan.Anak-anak juga sudah bisa diajak untuk membantu guru membereskan kelas atau peralatan belajarnya.Anak-anak yang berusia 56 tahun umumnya sudah bisa membereskan tempat makan atau bekal nya setelah makan.Anak-anak dengan usia 5-6 tahun sudah bisa $\mathrm{BAB}$ dan $\mathrm{BAK}$ di kamar mandi, mereka juga rata-rata telah mengkonsumsi makanan sehat dan tidak jajan sembarangan. Kebersihan badan dan menggosok gigipun juga sudah di laksanakan dimana keadaan fisik mereka terlihat bersih dan segar serta gigi merekapun tampak putih juga bersih hal ini menunjukan adanya pelaksaanaan hidup sehat pada diri anak. Anak juga sudah mampu untuk memperhatikan kebersihan kuku, hal ini dikarenakan adanya pemeriksaan kuku yang selalu dilakukan oleh guru sehingga anak menjaga kebersihan kuku mereka agar tidak panjang dan kotor.

\section{Kelebihan dan Kekurangan}

\section{a. Kelebihan}

TK Harapan Pertiwi Desa Anggalomoare merupakan salah satu contoh sekolah yang telah berusaha memberikan perhatian terhadap penanaman Perilaku HidupSehatpada anak usia dini. Selain itu fasilitas untuk melaksanakan pembiasaan perilaku hidup sehat pun sudah ada seperti tempat sampah, poster-poster kesehatan, alat P3K dan fasilitas kesehatan lainnya.Sehingga memudahkan bagi anak untuk berperilaku hidup sehat. TK Harapan Pertiwi Desa Anggalomoare juga sudah melaksanakan makan siang bersama sehingga anak tidak diajarkan untuk jajan sembarangan, selain itu kerja sama yang baik antara TK Harapan Pertiwi dan instansi lainnya seperti puskesmas sudah terjalin dengan baik.

\section{b. Kekurangannya}

TK Harapan Pertiwi dalam pelaksanaan pembiasaan hidup sehat dalam pelaksanaannya masih kurang pengawasannya.Sehingga pelaksanananya terkadang tidak sesuai dengan harapan dan tujuan pendidikan.Kegiatan pembelajaran kesehatan yang dilakukan hanyalah sebatas anjuran namun tidak diikuti dengan pengawasan, sedangkan tugas seorang guru selain memberikan arahan juga seharusnya melakukan pengontrolan dalam pelaksanaannya.

Penulis juga sering menemukan jarang tersedianya alat kesehatan seperti sabun untuk cuci tangan dan serbet bersih dan kering, sehingga anak tidak dapat melakukan cuci tangan dengan baik dan benar.Kurangnya media pembelajaran yang mendukung pembelajaran pendidikan kesehatan bagi anak.Kegiatan pembelajaran juga dirasakan hanya seperti ituitu saja. Guru jarang melakukan metode dan 
setrategi yang bervariasi, media yang digunakan umumnya hanya diambil dari LKS saja, dengan melipat dan menggunting, muatan pendidikan kesehatan belum begitu dimasukan dalam kegiatan sehari-hari dengan baik. Kurangnya sarana yang menunjang untuk proses pendidikan kebersihan, seperti tempat cuci tangan khusus sehingga cuci tangan hanya dilakukan secara manual dengan menimba air menggunakan gayung dari dalam bak air, sehingga terkadang anak antrian lama.Kegiatan cuci tangan tidak terkontrol, dan terkadang becek.

Dari hasil wawancara banyak guru yang mengeluhkan minimnya pelatihan yang didapat dari dinas kesehatan. Kegiatan pembelajaran dirasakan mulai membosankan, hal ini diperlukan penyegaran pada guru untuk diberikan berbagai pelatihan tentang strategi belajar-mengajar, metode dan jenis alat peraga, tumbuh kembang anak dan juga kegiatan lainnya.Sehingga guru kurang variasi dalam melaksanakan kegiatan pembelajaran.

\section{Respon Orang Tua Terhadap Pelaksanaan Pembiasaan Hidup Sehat di TK Harapan Pertiwi Desa Anggalomoare}

Berdasarkan hasil wawancara yang dilakukan penulis dengan beberapa orang tua murid, mereka mengemukakan pelaksanaan pendidikan kesehatan dalam hal ini pembiasaan perilaku hidup sehat juga telah mereka laksanakan di rumah. Hal ini dilihat dengan seringnya mereka melakukan pembiasaan pada anak-anak mereka seperti menggosok gigi, mandi, memotong kuku, tidak membuang sampah sembarangan, menggunakan pakaian yang bersih, BAB dan BAK harus dikamar mandi/WC, mencuci tangan sebelum dan sesudah makan serta memberikan makanan sehat untuk anak mereka. Ini menunjukan bahwa adanya perhatian dan kesadaran dari mereka dalam menjaga kesehatan anak-anak mereka walaupun juga terkadang ada kendala yang harus mereka hadapi dalam membiasakan anakanak misalnya anak susah untuk menggosok gigi dan mencuci tangan ketika disuruh sehingga mereka harus merayu dan membujuk agar anak dapat melaksanakannya.

\section{SIMPULAN DAN SARAN}

\section{Simpulan}

Berdasarkan hasil penelitian lapangan dan analisis, dapat ditarik kesimpulan sebagai berikut: TK Harapan Pertiwi adalah lembaga pendidikan anak usiadini yang telah menyelenggarakan perilaku hidup sehat di lingkungan TK Harapan Pertiwi. Adapun perilaku hidup sehat yang dilaksanakan di TK Harapan Pertiwi antara lain: pembiasaan cuci tangan, membuang sampahpada tempatnya, menggosok gigi, mengkonsumsi makanan sehat, potong kuku, berpakaian bersih, dan memanfaatkan jamban dengan baik. Adapun pelaksanaannya dilakukan melalui pembiasaan sehari-hari di sekolah. Akan tetapi, pembiasaan yang sudah dilaksanakan tersebut masih kurang pengawasan sehingga pembiasaan perilaku hidup sehat perlu ditingkatkan lagi.

\section{Saran}

Setelah melaksanakan penelitian pada anak serta hasil yang diperoleh melalui pengamatan yang dilakukan mengenai perilaku hidup sehat, maka peneliti menyarankan hal-hal sebagai berikut: (1) Bagi Kepala Sekolah, hendaknya kepala TK melaksanakan fungsinya dalam memanagesekolah.Hal ini karena pelaksanaan pelaksanaan perilaku hidup sehat di TK Harapan Pertiwi saat ini sudah mengalami penurunan. Semangat dan komitmen untuk tetap menanamkan pendidikan dan pembiasaan hidup sehat mulai menurun sehingga dengan peran aktif dari kepala sekolah dalam melakukan controling dan fungsi-fungsi managemen sangat diperlukan.; (2) Bagi Guru, diharapkan guru selalu melakukan pengawasan dalam pembiasaan perilaku hidup sehat sangat dibutuhkan agar pembiasaan-pembiasaan yang sudah dijalankan dapat berjalan dengan baik sesuai harapan yang ingin dicapai dan tidak hanya sekedar anjuran saja; (3) Bagi Orang Tua, hendaknya orang tua dapat menjadi contoh yang baik terhadap anak dan juga membiasakan perilaku hidup sehat untuk dirinya sendiri dan juga pada anaknya.

\section{DAFTAR PUSTAKA}

Anis, Muhammad.2009. Sukses Mendidik Anak Perspektif al-Quran dan Hadis. Yogyakarta: Pustaka Insan Madani.

Aqib, Zainal. 2009. Belajar dan Pembelajaran di Taman Kanak-Kanak. Bandung : Yrama Widya.

Ardiani, Yogi. 2013. Perkembangan dan Pemeliharaan Kesehatan AUD.[Online]. Tersedia: http://edukasi.kompasiana.com/perkemb 
angan-dan-pemeliharaan-kesehatanaud.html , [23 Desember 2016].

Arfiana, Mia. 2015. Gaya dan Pola Hidup Sehat. [Online]. Tersedia: http://www.yhschurch.com/gaya-hidupsehat-dan-pola-hidup-sehat/, [ 27 Desember 2016]

Daradjat, Zakiah. 1996. Pendidikan Islam dalam Keluarga dan Sekolah. Jakarta: YPI Ruhama.

Darajat, Zakiah. 2005. Ilmu Jiwa Agama. Jakarta: Bulan Bintang.

Habeahan, Jariston. 2009. "Pengetahuan, Sikap Dan Tindakan Perilaku Hidup Bersih Dan Sehat Anak-Anak". Skripsi. Medan: FKM USU.

Ibnatul Anis M, dkk. 2013. Ilmu Psikologi Dan Kesehatan.Jakarta : EGC.

Irianto, Koes. 2014. Ilmu kesehatan Anak. Bandung: Alfabeta.

Nata, Abudin. 2002. Pemikiran Para Tokoh Pendidikan Islam.Jakarta : PT. Raja Grafindo Persada.

Notoatmodjo, Soekidjo. 2003. Ilmu kesehatan Masyarakat. Jakarta: Rineka Cipta.

Notoatmodjo, Soekidjo. 2007. Promosi Kesehatan dan Ilmu Perilaku. Jakarta: Rineka Cipta.

Notoatmodjo, S. 2010. Ilmu Perilaku Kesehatan. Jakarta : Rineka Cipta.

Sera, Fina. 2012. Pola hidup sehat. [Online]. Tersedia:

http://www.blogspot.co.id/2012/09/penj

askes-pola-hidup-sehat.html. [ [ 24 Desember 2016]

Siswanto, Hadi. 2009. Pendidikan Kesehatan Anak Usia Dini. Jakarta : Pustaka Rihama.

Suliha, Uha. 2001. Pendidikan Kesehatan, Buku Kedokteran. Jakarta : EGC.

Sumarsini, Sri. 2013. "Strategi Guru Dalam Membelajarkan Perilaku Hidup Sehat Anak". Skripsi. Kendari: FKIP UMK.

Sunaryo. 2004. Psikologi Keperwatan. Jakarta : EGC.
Syahreni, E. 2011.Mengembangkan Perilaku Sehat Pada Anak Usia 2-4 Tahun. Jakarta : Direktorat Jenderal Pendidikan Anak Usia Dini Nonformal dan Informal Kementerian Pendidikan Nasional.

Undang-Undang RI No 20 Tahun 2003.Tentang Pembiasaan.

Undang Republik Indonesia No 36 Tahun 2009. Tentang Kesehatan. 